\title{
THE ROLE OF TRUST IN COOPERATION BETWEEN FARMERS - THE OUTCOMES OF A SURVEY IN BÉKÉS COUNTY
}

\author{
Takács István ${ }^{1}$ - Takácsné György Katalin² \& Baranyai Zsolt ${ }^{3}$ \\ ${ }^{1}$ Károly Róbert College, Institute of Business Sciences, itakacs@karolyrobert.hu \\ ${ }^{2}$ Károly Róbert College, Institute of Economics and Methodology, \\ tgyk@karolyrobert.hu H-3200 Gyöngyös, Mátrai u. 36. \\ ${ }^{3}$ Szent István University, Faculty of Economics and Social Sciences, Institute of Economics and Methodology, \\ baranyai.zsolt@gtk.szie.hu
}

\begin{abstract}
Local socio-economic cooperation arrangements can contribute to the development of adequate solutions which can compensate the negative impacts of globalization. One of the specific areas is agriculture. Capital-intensive technology is the key element in the competitiveness and viability of firms. The present paper reviews the factors affecting the joint machine use arrangements of agricultural producers, with special regard to the role of trust. The questions of trust are examined in two dimensions: contractual and competence trust. On the basis of the survey carried out among farmers a positive connection was detected between the level of trust and the farmers' activity in cooperation arrangements. Our results also pointed out that the trust needed in different areas of cooperation is very different. The experiences indicate a tendency, according to which contractual trust is more important in intensive cooperation arrangements which result in higher dependence, while competency trust is more emphasized in more extensive solutions.
\end{abstract}

Journal of Economic Literature (JEL) code: Q13

Keywords: cooperative behaviour, loyalty, competence, data survey, empirical model

\section{Introduction, raising questions}

David Korten triggered a debate in the early 1990s with his famous book "When corporations rule the world" in which he considered the appreciation of local communities, the growing weight of the local economy and the stimulation of cooperation between those involved in the economy as an adequate response to the negative phenomena of a globalizing world. [Korten 2002] Without reviving that debate, it can be stated that the role of local business cooperation has once again become important in Hungary, as well as in other countries of the Central Eastern European region.

Several forms of business cooperation have been introduced in recent decades which can be classified, for example, by the closeness of the relationship between cooperating partners and the degree of institutionalization regarding the form of arrangement (the degree of mutual dependence between partners).

The organizational approach to cooperation in the literature references typically appears as the review and evaluation of cooperatives, as the typical (most widely known and implemented) form. In many volumes of the Economic Review (Közgazdasági Szemle), the articles on this subject confirm this observation. It should be added, however, that the findings regarding cooperatives, as models of cooperation, can also be explained to a great extent as attributes of other forms of cooperation. In this respect, the examination of the theoretical relations of the cooperative model and the analysis of responses given to the impact of the changing socio-economic environment can help to highlight the internal coherencies of other forms of cooperation.

The cooperative form itself is a classic organizational model, the roots of which go back more than a hundred years, and the changes it has undergone in Hungary (primarily in agriculture) have occurred in the framework of very particular and contradictory processes before, as well as after, the post-socialist transition. [Kispál-Vitai 2006]

The development of cooperation arrangements indicate that, while keeping the principles of classic models, the interests of owners - which are better expressed as market relations and interests - have become prioritized to the product line. It also suggests that, for example, the much modelized Dutch cooperatives do not have any direct social objectives. [Szabó 2005] At the same time, the machine and farm assistance ring, as a model of cooperation - which has a shorter history, but has already become a world-wide movement, too - also has social functions in local communities. [Takács 2000] 
According to one classification, cooperation can be horizontal and/or vertical, where horizontal cooperation can strengthen the bargaining position of those (horizontally coordinated) in the vertical line. [Fertö 1996] This synergy can be observed in some product chains in Hungary (fruit and vegetables, the broiler chain) [Felföldi 2009; Szöllösi 2009; Dudás - Takács-György 2099]

There is a relationship between the size of business actors on the market and the bargaining position; therefore joint work and cooperation which increases market presence has an important role (the cooperative and producer organization is highlighted primarily as an organizational solution). [Szabó Bárdos 2007] By not differentiating among the organizational solutions in regards to cooperation, and using the concept of the virtual firm, it can be proved by the examination of (a virtually created) size unit and firm efficiency that coordination can help to increase the individual and joint efficiency of participating firms and thus an improvement in an important factor of their efficiency can be achieved. [Takács 2004]

Cooperation becomes inevitable among agricultural producers because there are several economic actors (a vast number and with different weights) parallelly in competitive positions and they face other monopolistic or oligopolistic economic actors who can use their dominance against divided partners who are unable to cooperate and can only enforce their interests weakly. Competitive and cooperative behaviour can be simultaneously present among the players of the market economy and cooperation ability is as important for them as the competitive spirit. These players will be strong, however, only if the ties to state are broken and those involved bear the consequences of their decisions. Cooperative behaviour requires trust, but the permanent presence of a "protecting net" weakens the urge and willingness to cooperate. [Hámori et al. 2007] The role of cooperatives is increasing in countries which are also simultaneously developing agriculture. [Ševarlić et al. 2011]

Cooperation plays an important role not only in the improvement of a bargaining position but also in the increase of efficiency of the means of production and the capital employed in them. [Takács 2008] A distinction should be made between technical and economic efficiency: what is technically efficient is not necessarily efficient in economic terms. [Zalai 2008] The cooperation arrangements reviewed in the present paper help to increase not only the technical efficiency of technical equipment, but also the economic efficiency of capital realized in it.

\section{Theoretical principles}

\subsection{Theoretical foundation of cooperation in economics}

Kispál-Vitai [2006] introduces the theoretical aspects of the subject in detail in the above cited article; therefore the present paper highlights those aspects of the subject which are not dealt with in the article.
In agriculture farmers (also) cooperate with different groups during their business activities; they conclude oral or written agreements or contracts. The contractual agreements and organizational structures set up in this form are one of the most analysed areas of new institutional economics.

In some theoretical approaches of new institutional economics $^{1}$, the different aspects of cooperation agreements are the focus of attention: the issue of asymmetric information is typically discussed by the agency theory, the areas connected with the costs of contracting are targeted by the theory of transaction costs, while the question of socalled remaining controlling rights is covered by the theory of property rights. The individual theories, of course, overlap each other in many respects but the different theoretical approaches are extremely useful in the differentiated examination of arrangements. From the perspective of current research the theory of transaction costs and the principal-agent theory are relevant.

Transaction cost theory/economics (TCE) can basically be regarded as an explanatory model which offers a theoretical basis for understanding the different organizational structures. The first milestone in the theory was the work of Coase [1937] (The Nature of the Firm). Other outstanding works in the development of the theory are Coase [1960], and Williamson [1979], [1985].

Summing up the conclusions of the works published on the subject, the theory holds that in business life the cost structure determines the organizational framework of transactions and the transaction costs significantly affect it. Those costs can be regarded as transaction costs which emerge in connection with market processes, market transactions or exchanges. According to Williamson [1979] three groups of transaction costs can be distinguished, namely: costs connected with collecting information, with concluding a contract and with controlling. The level of these costs depends on three factors of the contract: transaction specific investment, uncertainty and frequency of transactions [Williamson 1985].

The theory of transaction costs discusses three possible institutional solutions on the basis of the three cost determinants above. These are as follows:

- classic, short-term contracts, actually market exchange relations;

- neoclassic, long-term contracts, the so-called hybrid solution;

- relation contracts, which eventually mean the realization of transactions within organizational frameworks.

In the following, machinery sharing relations are reviewed. The technical equipment used in agricultural production is, on the one hand, typically regarded as a specific investment, because it can be used and converted to tasks different from the ones originally intended relatively

\footnotetext{
1 Kieser [1995] divides the theories of new institutional economics as follows: agency theory, property rights theory and transaction cost economics.
} 
inflexibly. On the other hand, it cannot be regarded as a specific investment because there are many partners in the narrow environment of the investor with whom the transaction can be made and vice versa; so there can be several alternatives for the firm to purchase the required machine capacities. Consequently the evaluation of asset specificity issues is not clear at all; it can be strongly differentiated both in space and time.

There are two qualified cases of uncertainties during transactions. One is the so-called parametric uncertainty, that is the uncertainty connected with the outcome of the transaction; the other is behaviour uncertainty (moral hazard, problems with keeping contacts, etc.) which can be traced back to opportunistic behaviour [Kieser 1995]. Since the agricultural production process is determined in time and the optimal time interval is rather short for carrying out the machine work, the timeliness cost can be very high and this results in considerable uncertainty. It is important to note that the assessment of uncertainty (also) includes many subjective elements in machinery sharing arrangements.

The frequency of transactions in regard to agrotechnical work operations is typically low because the working steps necessary to produce a crop should mostly be made once or twice a year.

On the basis of the - highly simplified - theory, the purchase of required machine capacities (transactions) for the agricultural firms can be made in the framework of three institutional solutions. Capacities can be ensured on a market basis by occasional, short-term rented machine services, while the so-called hybrid form is the virtual (large-scale) farm, as an alternative, where capacities are purchased in the framework of long-term agreements. The organized institutional solution in this case is the farm's own, independently realized machine investment.

Summarizing the above: the theory clearly confirms that the purchase of required machine capacities in Hungarian agriculture would be the most efficient in the framework of neoclassic arrangements; i.e. virtual large-scale farms.

According to the classic approach, the agency theory focuses on the contract and its role in the relationship between actors (basically the principal and the agent). When examining the cooperation between farmers, the agency theory - especially its normative direction, the principalagent theory - mainly stresses asymmetric information and related opportunistic behaviour. Asymmetric information although to different degrees - is always present if two or more parties conclude an agreement. As regards principalagent theory the literature basically distinguishes two types of problems among cooperating partners due to information asymmetry: moral hazard and adverse selection. The issue of adverse selection is not discussed in the present paper; in this regard see, for example, the work of Akerlof [1970].
Moral hazard appears when at least one input cannot be detected in the cooperation process and its quantity cannot be laid down in the contract [Royer 1999]. When the economic problem is raised ${ }^{2}$, many authors discuss the possible elaboration of an optimization scheme in this context. Many special models were set up in the relevant literature in connection with principal-agent theory; these are as follows: the multiple tasks model [Holmstrom - Milgrom 1991; Sarker, 2011]; the double moral-hazard model [Agrawal 2002]; the team production model [Alchian-Demsetz 1972]. As regards our topic this latter model has relevance. The team production model deals with the situation as a basic case when production is performed by several actors. In general, cooperation between actors can be much better defined as a network of relationships between actors (agents), than as a principal-agent relationship. As regards machinery sharing arrangements, however, it often happens that the farmer temporarily fulfils the role of principal, followed by that of agent; these roles are exchanged from time to time partly due to deterministic, and partly to random, factors.

In the literature of team production, the issues of moral hazard are discussed in detail by Holmstrom [1982]. The core of his approach is as follows: if the partners in the group are rewarded on the basis of the joint efforts and at least one input cannot be observed by the others, it will encourage the agents to withdraw from joint work (free rider behaviour). Eswarten - Kotwal [1985] introduced managerial skills as an example in agriculture. If the managerial skills are good - i.e. the skills cannot be detected by the other partners in making the right production decisions - this can be a reason to hide them within the partnership. This behaviour is due to the fact that each agent receives only a certain share of the total profit, but the total costs of his efforts should be paid. Agents can increase or maximize their profit only by decreasing their costs and an obvious way to do this is to decrease efforts. This type of moral risk is called "effort moral hazard" in the literature.

Another type of moral hazard is discussed by Hart [1995]. If inputs (e.g. machinery, equipment, instruments, etc.) are shared among agents in the production process, this will encourage them to use these assets excessively or to misuse them, because the user of the assets does not consider the full value of the assets because they are not, or are only partly, owned by him. This hazard is the so-called "asset moral hazard". In this case the information asymmetry comes from the imperfect controlling rights over the machines since they are in joint use or rental, or lent to other farmers. The limited observability may cause damage to the assets because the necessary repairs or maintenance work are not carried out.

Many authors have tried to solve the moral hazard problem in the team production model. They mostly agree

\footnotetext{
2 The basic problem is also mentioned by the literature as the landlord-tenant problem in connection with share farming [Stiglitz 1974]. The landlord is not fully aware how much the profit can be owed to the efforts of tenant. This limited observability can result in the agent (tenant) not ensuring proper, optimum effort from the viewpoint of the principal (landlord); in other words the agent is stimulated to reduce his performance, to "idle", and thus to use the resources for own purposes.
} 
that the key factors in reducing risk are peer pressure, social norms [Kandel - Lazear 1992; Barron-Gjerde 1997; Allen - Lueck 1998], and dynamics [Radner 1986].

The peer pressure or peer influence model is based on the concept that the members of the group are afraid of the consequences of breaking the written and unwritten rules, i.e. the social norms of the group. The partnerships among farms are often interwoven with the personal relationships among farmers, such as friendship, kinship or neighbourhood, therefore the behaviour which results in moral hazard can be very "expensive" in a social sense.

Kandel - Lazear [1992] - as far as we know - was the first to discuss peer pressure in fending off moral hazard and grouped the pressure exerted by the group into external (sin, guilt) and internal (shame, embarrassment) impacts. According to this, it was concluded that peer pressure is the result of social norms, since if one member of the group differs from the standards set by the group, he can face unfavourable impacts. Furthermore, the authors also examined the possibility of mutual observation among the members of the group. This concept was further developed by Barron - Gjerde [1997]. The role of peer pressure and monitoring was analysed with a sequential game theory approach and the introduction of a principium. The results confirmed that - in theory - a "leader" appointed within the group can be an appropriate way to decrease moral hazard.

Radner [1986] examined the role of dynamics in his paper by using repeated "games". The point here is that if there are several time periods (supergame), the members of the group are able to observe each other's efforts or at least the signs which may refer to the degree of effort exerted by other members of the group in the previous period. This ultimately solves the problem of moral hazard because in this case we cannot speak about information asymmetry.

Empirical testing of theoretical relationships regarding moral hazard has been undertaken by many authors. Larsen [2007] examined the question in Swedish agriculture and concluded that moral hazard exists among cooperating farmers. Moreover he confirmed the role of social norms in reducing moral hazard. His results also draw attention to the importance of trust and identified the level of trust as a key factor in treating moral hazard as well as in the development and efficient operation of cooperation itself. In Hungary the relationships of cooperation among farmers and moral hazard were examined by Baranyai et al. [2010]. They concluded that the machinery sharing arrangements are full of moral hazard but they also confirmed that the impact of moral hazard in itself is not relevant and does not explain the low cooperation activity which is typical in Hungarian agriculture.

The present study can be regarded as a close continuation of the above research in which the questions of trust emerging as a supplement to moral hazard - are examined in machinery sharing arrangements. In the following the trusttheories providing the actual theoretical frameworks of the research are reviewed.

\subsection{The role of trust in cooperation among farmers}

Trust has an outstanding role in human relations, and consequently in the field of cooperation among farmers, too. Over the last twenty years the issues of trust - as a research topic - has become the focus of interest in many fields of science.

It is widely accepted among experts in different scientific fields that the concept of trust presumes the presence of uncertainty or risk [Rousseau et al. 1998]. In this approach, trust is a possible tool for business actors to cope with the uncertainty or risk in exchange relations, behind which lie information and time problems. This is because in social relations - in addition to differing sources of information the responses are often delayed in time and the first steps must be made without being (fully) aware of the reaction of the counterpart. A certain degree of trust is needed for this [Lane - Bachmann 2000].

Trust, as a subject of research, is a relatively new phenomenon in the economic sciences, but a vast number of publications have appeared on the topic in the last 25 years (e.g. McAllister [1995], Sholtes [1998], Borgen [2001], Hansen et al. [2001], Szabó [2010], Bakucs et al. [2012], Fertö [2012], etc.) The present paper does not describe the different trust theories in detail, because many authors have done so recently (see for example the works by Csabina et al. [2001], Tóth [2004] and Nagy - Schubert [2007]. Instead, we concentrate on those aspects which are important for our subject.

The Sholtes trust model was the starting point in our research as we used the outcomes of our previous research projects [Takács et al. 2005]. Sholtes [1998] placed trust in the matrix of loyalty and capability. We can speak about trust if faith in loyalty as well as in capability has a high value among the partners (Figure 1).

\begin{tabular}{|c|c|c|c|}
\hline \multicolumn{2}{|c|}{} & \multicolumn{2}{|c|}{$\begin{array}{c}\text { Degree of competence } \\
\text { "I believe that my partner is well } \\
\text { trained and capable }\end{array}$} \\
\cline { 2 - 4 } & low & high \\
\hline $\begin{array}{c}\text { Degree of loyalty } \\
\text { "I believe that my partner } \\
\text { likes me and will support me } \\
\text { in the future" }\end{array}$ & high & SYMPATHY & TRUST \\
\cline { 2 - 4 } & low & DISTRUST & RESPECT \\
\hline
\end{tabular}

Figure 1: Trust among business partners on the basis of their loyalty towards each other and presumed capabilities

Source: on the basis of Sholtes [1998]

The basic model was adapted with some modifications. Out of the vast number of trust dimensions in the special literature we selected the approach used by Sako [1992]. He says that trust occurs when the business partner expects the other to behave predictably and in a mutually acceptable way. Discussing the types of trust Sako distinguished among others - contractual trust and competence trust. (1) Contractual trust: based on the mutually accepted norm of honesty and keeping promises, one of the contracting parties expects the other to keep his promises. (2) Competence trust: the business partner trusts that the other has the appropriate 
technical and managerial competence to fulfil the commitments. These two types of trust were implemented in the Sholtes model.

\section{Primary data sources}

Our examinations are based on primary databases. In order to explore the relations between trust and cooperation willingness in machinery sharing arrangements we carried out a questionnaire survey in South-Eastern Hungary, in the Southern Great Plain region, in Békés county. The research involved private farmers of three statistical micro regions, namely Orosháza, Békéscsaba and Mezőkovácsháza.

The selection of the sample was made with random sampling and the so-called snowball method. The survey was carried out between November 2008 and October 2009, for the financial year of 2007-2008. The criterion for involvement in the sample was the use of at least 1 hectare of agricultural land as well as the ownership of 1 technical resource (engine or machine) which can be used for agricultural purposes. In terms of status only private farms were included.

In the first run, information was collected with a preliminary questionnaire. The questions - among others covered the following fields:

- general information about the head of the farm (gender, age, education, income dependence on agricultural activities, etc.);

- general information about the farm (activities, size of rented and owned land, size of livestock, etc.);

- natural indices of farming (production structure, outputs, machine supply, etc.);

- main aspects of cooperation arrangements (form and frequency of cooperation, awareness of institutionalized forms of cooperation and the opinion of the farmer about these solutions, etc.); and

- questions of trust.

The present paper introduces the results, explaining the relations between trust and willingness to cooperate.

In a narrow group of farmers the questionnaire survey was complemented with deep interviews. The respondents were randomly selected from those farmers who were willing to reply. The deep interview questions were connected with the questionnaire topics; they served as a control, or a more detailed description of topics. The data collection in this form concerned three villages.

In the questionnaire survey information was collected from a total of 147 private farms, but 15 farms were excluded from further examination during the data processing owing to deficient completion of questionnaires. Therefore the results published below are all based on the data of 132 farms $(\mathrm{N}=132)$. Deep interviews were made on 23 out of the private farms surveyed with questionnaires.

The following presumptions and criteria were used for the development of the model for analysis (on the basis of experiences which were not factually examined during the present research) - on the analogy of the tank model:
- the selected regions - regarding the agricultural services targeted by the examination - form a closed system: the examined services going out from the region and the services coming into the region are much less than the services performed among the farmers within the region;

- the parties should know each other and the relational networks should be mappable in order to examine trust;

- as regards geographical, economic, cultural and social criteria, the examined microregions can be regarded as one system, and concerning the above factors they do not significantly differ from other Hungarian regions (this presumption is based on the relatively homogenous national dispersion of registered cooperation arrangements).

On the basis of the conditions the possible number of elements in the sample is limited. In a statistical sense, the sample is not representative at national or county level, but it is representative at local level. Due to this, if our presumptions regarding the closed system are met - which is confirmed by other research, too - the findings concerning the region examined can be generalized because there are no considerable economic or social differences between the key agricultural areas of the country.

\section{Applied empirical models}

\subsection{Definition of areas of machinery sharing, models for measuring}

Cooperation, as an expression, is a broad concept - even considering machine use - and it can be implemented in many forms. During the research - based on former research experiences (Takács et al. 2005 and 2006) - we have developed a typology in which the different forms of cooperation form a structure in the context of trust and dependence (Figure 2). We distinguished cooperation dimensions in a "wider" and "narrower" sense in the elaborated hierarchical structure, of which the results connected with the narrow approach are described in the present paper.

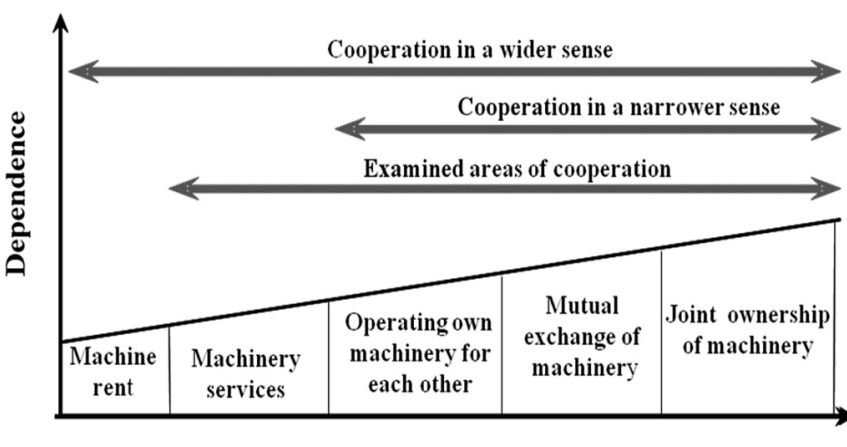

Trust

Figure 2: Machinery sharing arrangements in the context of dependence and trust levels

Source: Authors'own editing 
In the following we summarize the main points of each field of cooperation and the methodology for quantifying farmers' activity within them.

(1) Machinery services based on mutuality (COOP_1): In our approach this solution is the most extensive form of cooperation. In this case we speak about agreements in which the farmer performs work with his own machinery for fellow farmers on a mutual basis. The respondents quantified the activity in the questionnaire by evaluating each work process on a scale from one to four. Utilizing this information, the following equation was set up to express the value of the activity rate:

$$
\text { COOP_1 } \sum_{i=1}^{n} v_{i} \quad \quad i=1,2,3 \ldots n
$$

where: $v_{i}=$ frequency of cooperation connected with work process No. $i$ [range 0-3: 0- never; 1- rarely: 1-2 times a year; 2- medium: 3-4 times a year; 3- frequent: more than 5 times a year]; $n=$ number of work processes [pcs].

(2) Mutual exchange of machinery (COOP_2): this solution indicates a machinery sharing arrangement where the farmer lends his own asset to his fellow farmer. According to the above concept, the activity can be described as follows:

$$
\text { COOP_2 }=\sum_{i=1}^{n} z_{i} \quad \quad i=1,2,3 \ldots n
$$

where: $z_{i}=$ the participation activity of agricultural machinery No. $i$ in cooperation [range 0-3: 0- never; 1- rarely: 1-2 times/year; 2- medium: 3-4 times/year; 3-frequent: more than 5 times/year]; $n=$ number of machines [pcs].

(3) Joint ownership and use of machinery (COOP_3): this is the most intensive form of joint machine use, where the farmers carry out a joint investment and share the acquired technical resource(s). In this case the activity rate was determined as follows:

$$
\mathrm{COOP}_{-} 3=\sum_{i=1}^{n} r_{i} \quad i=1,2,3 \ldots n
$$

where: $r_{i}=$ joint ownership of No. $i$ agricultural machinery of the farm [0, 1 dichotomic variables: 0 -no, 1 -yes $] ; n=$ number of machines [pcs].

Considering the three types of cooperation activity in a narrow sense we developed an aggregated willingness-tocooperate rate (WTC-rate) which describes the total cooperation activity of the observation units. We needed objective weights for correct and precise definition of indices. These weights should be rendered to the different areas of cooperation, thus expressing the different intensity of individual cooperation arrangements. The principal component analysis (PCA) helped us in the solution of the problem. We used the principal component weights in the so-called $\boldsymbol{A}$ matrix created by the multivariate statistical method. According to this, the aggregated index was determined as follows:

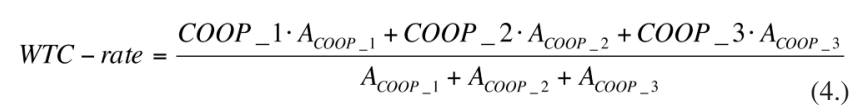

where: $W T C$-rate = aggregated index of cooperation activity in the case of the given observation unit [-]; COOP_x $=$ the value of activity rates that are typical in the individual areas of machinery sharing arrangements [-]; $A_{C_{C O O} \_x}=$ the linear correlation coefficient of cooperation arrangements with the principal component ( $\boldsymbol{A}$ matrix of PC-1) [-].

\subsection{Quantification of trust levels}

In order to examine the farmers' trust we collected information on the basis of the trust concepts detailed above. Two questions were used to measure the level of contractual trust and three questions for competence trust (see Table 1). The respondents evaluated the replies on a scale from 1 to 7 , where 1="I do not agree at all" and 7="I agree totally". The expression of each level of trust was achieved with a simple arithmetical calculation of the average.

Table 1: Questions used for measuring the trust level

Contractual trust

I think my fellow farmers definitely keep their word

I think my fellows would never do any harm to me if the conditions of farming changed

Competence trust I trust that if any of my fellow farmers provides any machine work for me, the quality of his work will be the best possible under the given conditions

I trust that if any of my fellow farmers provides any machine work for me, it will be done at the most appropriate time, under the given conditions I trust that if I lend a machine or tool to any of my fellow farmers, he will use it with the necessary precautions

Source: Authors'own editing

\subsection{Statistical methodology}

The general evaluation of information collected in the course of the survey and the detection of relations between data lines required the use of a wide range of statistical methodologies. Besides general descriptive statistics, multivariate statistical methods were used, too, of which the role of so-called "explanatory models" is highlighted in the discovery of relationships between variables.

Several statistical models were applied in the research to identify the factors which explain the cooperation activity of farmers. As is widely known, the selection of a methodologically correct explanatory model is strongly determined by the measuring level of dependent and independent variables. In most cases, the dependent variables were of high measuring level; metric variables (WTC-rate, COOP_1, COOP_2), for the explanation of which we have built different models depending on the measuring level of independent variables. When the independent variables were also of high measuring level, we used linear regression models ${ }^{3}$, while hierarchic ANOVA (ANalysis Of VAriance)

3 Due to methodological considerations, the activity rates of the COOP_3 form of cooperation were transformed into dichotomous variables: 1 cooperates; 0 - does not cooperate. In this case the binominal logistic regression model was the adequate tool for revealing interrelations. 
models helped to find the relationships in the case of (nonmetric) independent variables of low measuring levels. In the implementation of ANOVA models, since no standard categorization system was available, the conversion of existing metric explanatory variables into variables of low measuring level was made with the help of the Visual Bander function of the SPSS software package.

\section{Empirical results}

\subsection{Trust profile of farms}

The examination of trust was based on Sholtes' model [Sholtes 1998], in which trust can be evaluated from two perspectives, namely on the basis of the faith of farmers in loyalty and capabilities. Adapting the original model: loyalty in fact means an approach to trust which focuses on honesty and keeping promises. Faith in capabilities means that the fellow farmer, on the one hand, has the appropriate machinery to fulfil the obligations he undertakes, and, on the other, has those personal qualities with which the transactions can be performed without negative consequences. The questionnaire used two statements to measure the faith of farmers in the loyalty of fellow farmers, while three statements were designed to measure faith in the capabilities of fellow farmers. (Table 4)

On the basis of responses measuring trust in the loyalty of fellow farmers, it can be concluded that farmers have slightly more trust that their fellows would keep their word (average: 3.69), than that their fellows would not be opportunistic in the case of any changes (positive or negative) in the conditions of farming (average 3.47). The paired t-test confirmed that there is a significant difference between the averages of responses given to the two variables. The (contractual) trust in loyalty should have been expressed with an indicator for further examinations; therefore we used the simple arithmetic average of the responses given to the two questions. The average value of the indicator formed is 3.57 in the whole sample.

Trust in the competence of fellow farmers was measured by 3 questions. Two were used to evaluate the level of trust in the field of machinery services and one in the field of machine rental. The paired t-test made for the three questions did not reveal any significant difference between the averages in any of the pair alternatives. Thus it can be concluded that although the average values in the case of machinery services indicate a slightly higher trust level than in the case of machine rental, this difference is not significant in a statistical sense.

As regards trust in competence, the aggregated index was also formed with the simple arithmetical average of the three responses. Comparing the two trust dimensions, it was statistically proven by experience that the average level of trust in the competence of fellow farmers is higher (4.02) than faith in their loyalty (3.57).
Table 2: Typical figures of trust types

\begin{tabular}{|c|c|c|}
\hline Statements connected with measuring trust & Average & Dispersion \\
\hline $\begin{array}{l}\text { a.)I think my fellow farmers definitely keep their } \\
\text { word. }\end{array}$ & 3.69 & 1.96 \\
\hline $\begin{array}{l}\text { b.)I think my fellows would never do any harm to } \\
\text { me if the conditions of farming changed. }\end{array}$ & 3.47 & 2.05 \\
\hline Contractual (loyalty) trust & 3.57 & 1.97 \\
\hline $\begin{array}{l}\text { c.) I trust that if any of my fellow farmers provides } \\
\text { any machine work for me, the quality of his } \\
\text { work will be the best possible under the given } \\
\text { conditions. }\end{array}$ & 3.96 & 1.61 \\
\hline $\begin{array}{l}\text { d.) I trust that if any of my fellow farmers provides } \\
\text { any machine work for me, it will be done at the } \\
\text { most appropriate time, under the given conditions. }\end{array}$ & 4.13 & 1.65 \\
\hline $\begin{array}{l}\text { e.) I trust that if I lend a machine or tool to any of } \\
\text { my fellow farmers, he will use it with the } \\
\text { necessary precautions. }\end{array}$ & 3.95 & 1.60 \\
\hline Trust in capabilities (competence) & 4.02 & 1.50 \\
\hline
\end{tabular}

Source: Authors'own editing

There is another interesting - and important - finding: a statistically proven relationship was revealed between age and trust types. As regards direction, the relationship is negative, so the older the farmer, the lower the level of trust in the loyalty and competence of fellow farmers.

\subsection{Effect of trust on cooperation: trust in loyalty vs. competence}

Further on in our research we used regression models to examine the role of trust types in the different cooperation agreements. The main results of the examinations are summarized in Table $3^{4}$.

Table 3: Effect of contractual and competence trust on willingness to cooperate (table summarizing results of regression analysis)

\begin{tabular}{|c|c|c|c|}
\hline \multirow{2}{*}{$\begin{array}{c}\text { Explained } \\
\text { variable }\end{array}$} & \multicolumn{3}{|c|}{ Explanatory variable } \\
\cline { 2 - 4 } & SZERZ_BIZ [-] & KOMP_BIZ [-] & $R^{2}$ \\
\hline WTC-rate & $0.170^{*}$ & $0.304^{* *}$ & 0.14 \\
\hline COOP_1 & 0.000 & $0.327 * *$ & 0.09 \\
\hline COOP_2 & $0.241^{*}$ & $0.181^{* *}$ & 0.10 \\
\hline COOP_3 & 0.168 & $0.456^{*}$ & $0.113^{+}$ \\
\hline
\end{tabular}

+ Nagelkerke $\mathrm{R}^{2}$

** significant at 0.01 level

* significant at 0.05 level

Source: Authors' own editing

\footnotetext{
4 It should be noted that as the control of the statistical analysis, in order to exclude endogeneity and multicollinearity phenomena, the required control examinations were performed and validated the results. A further problem arose from the low $\mathrm{R}^{2}$ values. In this regard the significant ANOVA result models the idea that the small values are enough to confirm the validity of revealed relations for the base population.
} 
The value of aggregated cooperation activity (WTC-rate) was significantly determined by both the contractual and the competence trust levels in the multivariate linear regression model. As regards the power of explanatory variables, trust in capabilities was much stronger than trust in loyalty. The direction of impact - conforming to the expectations - was positive. The two explanatory variables together can explain the low value (13.5\%) of WTC-rate dispersion.

According to the statistics, the value of the activity undertaken in machinery services based on mutuality (COOP_1) is determined only by the trust in the competence of the fellow farmer. Trust in loyalty is highly independent from this. It confirms that this solution is the "most extensive" form of machine use arrangement, where the most important belief is that the fellow farmer can fulfil his commitments.

The multivariate model examining the questions of cooperation based on machine rental (COOP_2) has revealed some interesting results. Both explanatory variables have become significant model elements, but the $\mathrm{B}$ value indicated that the level of loyalty trust has stronger impact and can better explain the machine rental activity than trust in competence. Although the difference is slight in terms of explanatory power it is proven. The two variables in the model explain only $10 \%$ of the heterogeneity of cooperation activity.

The relationship between joint machine ownership (COOP_3) and the trust dimensions discussed were examined in the framework of binominal logistics regression. Analysing the individual impact of variables it was concluded that only the impact of trust in capabilities could be regarded as significant before setting up the model; the trust in loyalty was not significant. This partly contradicts expectations because it was presumed that the role of contractual trust was more determining at the highest level of cooperation. Following the setting up of the model $11.3 \%$ of the total dispersion - significant in total - could be explained, according to Nagelkerke $\mathrm{R}^{2}$. When the trust variables were entered in the model, the competence trust still maintained its significance so the given variable substantially contributed to the model. On the basis of this it was concluded that joint machine ownership, as a form of cooperation, is based mostly on trust in capabilities, although trust in loyalty has a non-negligible role, too, although this can only partly be proven statistically.

\subsection{Testing the Sholtes trust model}

The examination of relationships between trust and cooperation activity were complemented with the testing of the Sholtes model. Validation was based on the presumption that cooperation between farmers is the most likely if they trust each other. As was discussed above, Sholtes said that trust develops when the level of trust both in loyalty and competence is sufficiently high. According to this, it is easy to accept that cooperation will mostly be formed at a high level of loyalty and competence trust. This question will be analyzed below.

The trust scales regarding loyalty and competence trust are each divided into 3 parts: degrees $1-2=$ low, $3-5=$ median, $6-7=$ high levels ${ }^{5}$. Comparing the two dimensions, the average activity rate values are summarized in Table 4.

Table 4: Average values of cooperation activity rates in the trust dimensions

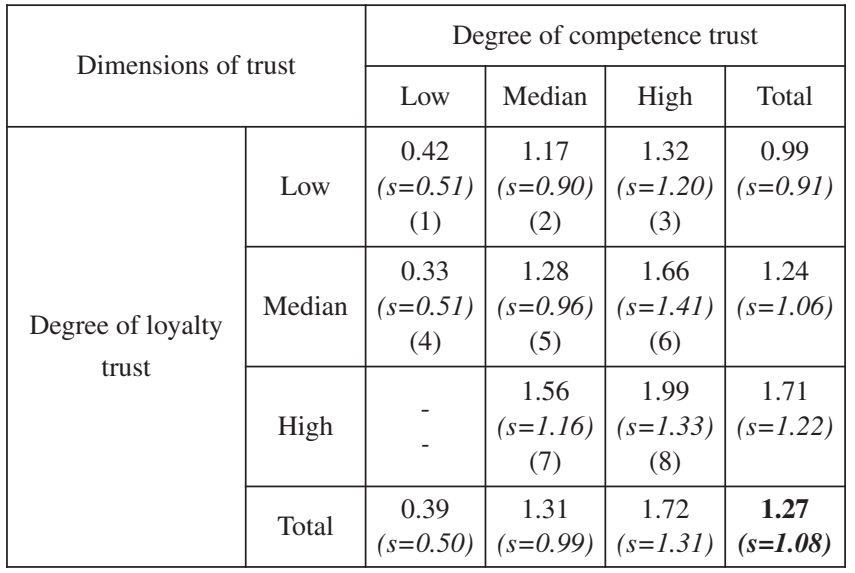

Source: Author's own editing

The methods of descriptive statistics indicated that the presumption based on Sholtes model was correct because low trust levels resulted in lower, and high trust levels resulted in higher, average activity values. In the case of the other trust level combinations, the values were essentially calculated between the two extreme values.

Control examinations were made in order to validate the results. The comparison of cell averages was made with the ANOVA model, complemented with post-hoc tests. Groups were formed for the examinations. On the basis of "trust cells" 8 groups were put together from the farms (no farm could be listed in one cell, which is why the number of groups was not 9). The results confirm that there is a difference between expected values at a 0.004 significance level. However, it indicates only the general difference between cell averages, and does not give detailed information about the cells concerned. The question can be answered with post-hoc tests. The most conservative, and thus most reliable, Scheffe-test on the basis of F sample dispersion proves that there is no group average where the expected values are significantly different from each other. By "softening" the trials with the LSD test, which uses a t-test to control the differences between averages, significant results could be revealed.

The results proved that, among other things, the cooperation activity of groups with perfect distrust (1) and unconditional trust (8) - using the titles in the original model - are significantly different from each other.

As regards group 3, which represents respect towards fellow farmers, the expected value of the activity rate is not

\footnotetext{
5 Note: histogram analysis was made before categorization and proved the levels through the "peaks" of frequencies.
} 
substantially different from the average of any other group. None of the farmers belonged to the category of pure sympathy - no such combination could be identified in the examined sample. The experiences collected in the more reserved group, i.e. with a median trust level, indicate that even the trust-approach based on the Sholtes model cannot give a perfect explanation for the cooperation activity of farms. The validation of the model, however, can be considered successful. Reviewing the results, it can be concluded that the trust in both loyalty and competence has an important role in machine use arrangements, although the model also proves that the weight and importance of trust types is not the same.

\section{Conclusions}

The paper examines the role of trust in machinery sharing arrangements. The results of empirical research carried out among agricultural enterprises in Békés county confirm that farmers gave wrong responses to the problems occurring in the new situation which emerged following the post-socialist transition. The new situation required strongly adaptive, innovative behaviour from farmers, in which cooperation mechanisms should have played a key role, but - according to experience - this has not happened in the last twenty years. The findings of the survey have led us to the conclusion that the changes in the political-economic environment have given - often contradictory - impulses to farmers and the encouragement of cooperation was not among these impulses. Thus willingness to cooperate nowadays is rather low.

The present paper examines the trust connected with machinery sharing, as one area of cooperation among farmers. The survey - made within a group of farmers in Békés county - confirmed a positive relation between the level of trust and farmers' activity in cooperation arrangements. Our results also point out that the trust demands of different areas of cooperation is differentiated. The experiences indicate a tendency according to which contractual trust is more important in intensive cooperation arrangements which result in higher dependence while competence trust is more emphasised in more extensive solutions.

Our research, of course, has certain limits. The generalization of the results is more difficult due to the low number of elements in the sample and the regional concentration of the sampling.

It also creates, however, the opportunity to carry on the research, specifically in two directions: on the one hand, by the quantitative expansion of the research - i.e. by increasing the number of elements and the area of data collection - and on the other hand, by qualitative expansion, i.e. by the empirical analysis of further trust models.

\section{Acknowledgements}

The study was made with the support of the National Scientific Research Fund (OTKA K63231)

\section{References}

Agrawal, P. (2002): Double moral hazard, monitoring, and the nature of contracts. Journal of Economics. 57 (1). 33-61.

Akerlof, G. (1970): The market for 'Lemons': Quality uncertainty and the market mechanism. Quarterly Journal of Economics. 84 (3). 488-500.

Alchian, A. A. - Demsetz, H. (1972): Production, information costs, and economic organization. The American Economic Review. 62 (5). 777-795.

Allen, D. W. - Lueck, D. (1998): The nature of the farm. Journal of Law and Economics. 41. 343-386.

Bakucs L.Z. - Fertő I. - Szabó G.G. (2012): Benefits of a marketing cooperative in transition agriculture: Mórakert purchasing and service co-operative. Society and Economy 34:(3) 453-468.

Baranyai Zs. - Vásáry M. - Mahesh K. S. - Takács I. [2010]: Moral hazard in machinery sharing arrangements - Some experiences from Hungary. The Annals of The Faculty of Economics Subotica. Vol. 46. 24/2010. 3-14.

Barron, J. - Gjerde, K. (1997): Peer pressure in an agency relationship. Journal of Labour Economics. 15 (2). 234-254.

Borgen, S. O. (2001): Identification as a trust-generating mechanism in cooperatives. Annals of Public and Cooperative Economics 72 (2). 209-228.

Coase, H. R. (1937): The nature of the firm. Economica 4 (16). 386-405.

Coase, H. R. (1960): The problem of social cost. Journal of Law and Economics. 3. 1-44.

Csabina Z. - Kopasz M. - Leveleki M. (2001): A szerződéses bizalom a hazai feldolgozóipari vállalatok üzleti kapcsolataiban. Szociológiai Szemle. 2001/1. 22-41.

Dudás Gy. - Takács-György K. (2009): Motivation factors for joining fruit and vegetable producer organizations (POs) from growers' viewpoint. Hungarian Agricultural Research. 18. (6) $10-15$.

Eswaran, M. - Kotwal, A. (1985): A Theory of contractual structure in agriculture. American Economic Review. 75. 352-366.

Felföldi J. (2009): Experiences on Organization of Fruit and Vegetable Sector in Hungary. Applied Studies in Agribusiness and Commerce (APSTRACT) 2. (5-6)

Fertő I. (1996): A vertikális koordináció a mezőgazdaságban. (Vertical Coordination in Agriculture) Közgazdasági Szemle 43. (11) 957-971.

Fertő I. (2012): Bizalom és szerződéses kapcsolatok a magyar élelmiszerláncban. In: Fertő I, Tóth J (eds.): Piaci kapcsolatok és innováció az élelmiszer-gazdaságban. Budapest: Aula Kiadó, 2012. 133-144.

Hámori B. - Szabó K. - Derecskei A. - Hurta H. - Tóth L. [2007]: Versengő és kooperatív magatartás az átalakuló gazdaságban. Közgazdasági Szemle. 54 (6). 579-601.

Hansen, M.H., MORROW JR. J.L, P., BATISTA, J.C. (2002): The impact of trust on cooperative member retention, performance and satisfaction: an exploratory study, International Food and Agribusiness Management Review. 5. 41-59.

Hart, O. (1995): Firms, contracts and financial structure. Clarendon Press.

Holmstrom, B. - Milgrom, P. (19914): Multitask principal-agent analysis: Incentive contract, assets ownership, and job design. 
Journal of Law, Economic and Organisation. 7. (Special Issue) 24-52.

Holmstrom, B. (1982): Moral hazard in teams. Bell Journal of Economics. 13 (2). 324-340.

Kandel, E. - Lazear, E. P. (1992): Peer pressure and partnerships. Journal of Political Economy. 100 (41). 801-817.

Kieser, A. (1995): Szervezetelméletek. Budapest: Aula Kiadó. 251-313.

Kispál-Vitai Zs. (2006): Gondolatok a szövetkezetelmélet fejlődéséről. Közgazdasági Szemle. 53 (1). 69-84.

Korten, D. C. (2002): Tőkés társaságok világuralma. Kapu Kiadó. Budapest. 451.

Lane, C. - Bachmann, R. (2000): Trust within and between organziations. New York: Oxford University Press. In: Csabina Z. Kopasz M. - Leveleki M. (2001): A szerződéses bizalom a hazai feldolgozóipari vállalatok üzleti kapcsolataiban. Szociológiai Szemle. 2001/1. 22-41.

Larsen, K. (2007): Participation, incentives and social norms in partnership arrangements among farms in Sweden. American Agricultural Economics Association Annual Meeting. Portland. OR, July 29-August 1, 2007.

McAllister, D. J. (1995): Affect- and cognitive-based trust as foundations for interpersonal cooperation in organizations. Academy of Management Journal 38. 24-59.

Nagy J. - Schubert A. (2007): A bizalom szerepe az üzleti kapcsolatokban. BCE. 77. számú Műhelytanulmány. Elektronikus anyag: http://edok.lib.unicorvinus.hu/115/01/Nagy-Schubert77.pdf. 25.

Radner, R. (1986): Repeated partnership games with imperfect monitoring and no discounting. The Review of Economic Studies. 60. 599-611.

Rousseau, D. M. - Sitkin, R S. - Burt, C B - Camerar, C. (1998): Not so different after all: a cross-discipline view of trust. Academy of Management Review. 23 (3).

Royer, S. J. (1999): Cooperative organizational strategies: A neoinstitutional digest. Journal of Cooperatives. 14. 44-67.

Sako, M. (1992): Prices, quality and trust. Interfirm relations in Britain and Japan. New York: Cambridge University Press. In: Csabina Z. - Kopasz M. - Leveleki M. (2001): A szerződéses bizalom a hazai feldolgozóipari vállalatok üzleti kapcsolataiban. Szociológiai Szemle. 2001/1. 22-41.

Sarker, D (2011): Moral Hazard Problem for Poor under Joint Forest Management Programme - Evidence from West Bengal in
Indian. Applied Studies in Agribusiness and Commerce (APSTRACT) 5. (1-2)

Ševarlić, M.M. - Nikolić, M.M. - Simmons, R. (2011): Agricultural Cooperatives and Their Membership in Cooperative Unions in Serbia. Applied Studies in Agribusiness and Commerce (APSTRACT) 4. (3-4)

Sholtes, P. R. (1998): The leader's handbook: Making things happen - getting things done. New York: McGraw-Hill.

Szabó G. G. - Bárdos K. (2007): Szerződéses kapcsolatok az élelmiszer-gazdaságban. A tejellátási lánc empirikus kutatása. Közgazdasági Szemle. 54 (5). 459-480.

Szabó G. G. (2005): A szövetkezeti identitás - egy dinamikus megközelítés a szövetkezetek fejlődésének gazdasági nézőpontú elemzésére. Közgazdasági Szemle. 52 (1). 81-92.

Szabó, G. G. (2010): The importance and role of trust in agricultural marketing co-operatives. MTA - AKI, Budapest: Studies in Agricultural Economics. 112. 5-22.

Szőllösi, L. (2009): "The Operation of the Hungarian Broiler Product Chain" Applied Studies in Agribusiness and Commerce (APSTRAC-T) 3. (5-6) 47-50.

Takács I. (2000): Gépkör - jó alternatíva? Gazdálkodás 2000. 44 (4). 44-55.

Takács I. (2004): Efficiency problems of farm assets in Europe. Annals of the Polish Association of Agricultural and Agribusiness Economists. 6 (6). 68-73.

Takács I. (2008): Szempontok a müszaki-fejlesztési támogatások közgazdasági hatékonyságának méréséhez. In Takács I (szerk.) (2008): Műszaki fejlesztési támogatások közgazdasági hatékonyságának mérése. Szent István Egyetemi Kiadó. Gödöllő. pp. 9-48.

Takács I., Baranyai Zs., Nagy I. (2006): A gépköri mozgalom helyzete, fejlődésének jellemzői Magyarországon 2005-ben. MTAAMB Kutatási és fejlesztési tanácskozás. Nr. 30. Gödöllő. 2006. january 24-25. Konferencia kiadványai I. kötet 120-125.

Tóth L. (2004): A bizalom szerepe a helyi gazdasági kapcsolatokban. Szociológiai Szemle. 2004/4. 95-128.

Williamson, O. E. (1979): Transaction cost Economics: The Governance of Contractual Relations. Journal of Law and Economics. 22 (2). 233-261.

Williamson, O. E. (1985): The economic institutions of capitalism. New York: The Free Press.

Zalai E. (2008): Műszaki és gazdasági hatékonyság Koopmans termeléselméletében. Közgazdasági Szemle. 55 (1). 3-24. 